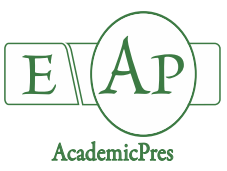

Puia A et al. (2021)

Notulae Botanicae Horti Agrobotanici Cluj-Napoca

Volume 49, Issue 2, Article number 12332

DOI: $10.15835 /$ nbha 49212332

Review Article

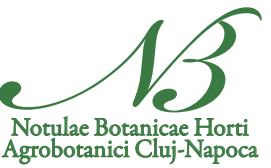

\title{
The phytochemical constituents and therapeutic uses of genus Aloe: A review
}

\author{
Aida PUIA ${ }^{1}$, Cosmin PUIA ${ }^{1,2 *}$, Emil MOIȘ ${ }^{1,2 *}$, Florin GRAUR ${ }^{1,2}$, \\ Alin FETTI ${ }^{1,2}$, Mira FLOREA ${ }^{1}$ \\ ${ }^{1}$ University of Medicine and Pharmacy "Iuliu Hatieganu”, 8 Victor Babes Street, Cluj-Napoca, Romania; draidapuia@gmail.com; \\ cosmin.puia@umfcluj.ro (*corresponding author);drmoisemil@gmail.com (*corresponding author); graurf@yahoo.com; \\ confetti_ro@yahoo.com; miraflorea@yahoo.com \\ ${ }^{2}$ Regional Institute of Gastroenterology and Hepatology "Prof. O. Fodor", 19-21 Croitorilor Street, Cluj-Napoca, Romania
}

\begin{abstract}
Aloe, the largest genus in the Asphodelaceae family, comprises 548 species, with $A$. vera, $A$. arborescens and $A$. ferox being among the most widely studied species. Aloe species originated in arid climates and cover various habitats, from sea level up to $2700 \mathrm{~m}$, and from desert to closed-canopy forests. For human health, Aloe species are the richest natural sources. The biological activity of Aloe sp. constituents covers a wide spectrum. Most of the indications come from traditional, folkloric use and several have been verified by in vitro or in vivo studies. Emodin, the main phenolic component, has showed anti-neoplastic, anti-inflammatory, antiangiogenic and toxicological potential for use in pharmacology. Polysaccharides, with acemannan being the most important, are present in high abundance in Aloegels. Acemannan has been reported to have applications in oral, metabolic and cardiovascular diseases, oncology, dentistry and wound healing. The effectiveness of Aloe sp. constituents on colon, liver, duodenum, skin, pancreas, intestine, lungs and kidneys cancers was highly studied with remarkable findings. Regarding the metabolic syndrome, Aloe sp. can be used as an antidiabetic and reduces cholesterol and total body fat. Constituents of Aloe sp. are nontoxic in experimental acute oral studies and are widely used in cosmetology and as bitter agents or consistence modifiers in food and beverages. Traditional Aloe remedies cover most human diseases; however, in order to gain legitimacy, the Aloe-derived drugs must have a well-established composition, with thoroughly investigated adverse effects and conventional drug interactions.
\end{abstract}

Keywords: Aloe, antidiabetic; antimicrobial; cancer; healing

\section{Introduction}

Aloe, the largest genus in the Asphodelaceae family, bears its name from the Arabic word "Alloeh," meaning shining bitter substances (Sánchez et al., 2020). The genus Aloe L. comprises 548 accepted species, with at least one-third having some commercial importance (Grace et al., 2009). A. vera, A. arborescens and $A$. ferox are among the most widely studied Aloe species. The Egyptians called Aloe the "Plant of Immortality" because they can live and even bloom without soil (Mukesh et al., 2010). The plant was widely used by the

Received: 01 Apr 2021. Received in revised form: 26 May 2021. Accepted: 28 May 2021. Published online: 03 Jun 2021.

From Volume 49, Issue 1, 2021, Notulae Botanicae Horti Agrobotanici Cluj-Napoca journal uses article numbers in place of the traditional method of continuous pagination through the volume. The journal will continue to appear quarterly, as before, with four annual numbers. 
Assyrians, Egyptians and Mediterranean civilizations (Moein et al., 2017). Dried leaf exudate is the principal medicinal product. Dioscorides used $A$. vera as a purgative, to treat mouth infections, wounds and other dermatological conditions (Grindlay and Reynolds, 1986). The purpose of this review is to highlight the characteristics of Aloe Plants with their compounds and pharmacological activities.

The Aloe genus comprises monoecious, perennial species with shallow roots. Aloe species thrive in arid climates in Africa (from where it probably originates) and India. Its adaptability, conditioned by temperature, rainfall, soil moisture and fire tolerance, allows Aloe species to cover various habitats, from sea level up to 2700 $\mathrm{m}$, and from desert shrub lands to closed-canopy forests (Salehi et al., 2018).

The most appropriate soil is a loamy mixture with $\mathrm{pH}$ 7.0-8.5, but some species ( $A$. vera) prefer acidic soils. Well-drained sandy soil or rocky sites are preferred, but many Aloe species can grow in almost any soil type. Several Aloe species may act as nurse plants, ameliorating harsh conditions in barren landscapes and increasing soil binding and stabilization in degraded rangeland (King and Stanton, 2008). The optimal growth temperatures range between $4-21{ }^{\circ} \mathrm{C}$. The blooming time is in May-June and the colour may vary depending on the soil mineral composition.

Most of the Aloe species are diploids ( $2 n=14)$. Polyploidy is uncommon in Aloe and is not uniform in its geographical distribution. The only known case of hexaploidy $(2 n=42)$ in the entire genus is $A$. ciliarisvar. ciliaris, whereas several other varieties of $A$. ciliaris are tetraploid $(2 n=28)$. The tetra- and hexaploids appear naturally as intraspecific autopolyploids, and the morphological differences between the varieties are quantitative rather than qualitative (Riley, 1959). There are reports of triploidy in Aloe $(2 n=21)$, with sterile but vegetatively vigorous individuals (Brandham et al., 1994).

Carl Linnaeus was the first to describe Aloe vera in 1753 as Aloe perfoliata var. vera, followed by Nicolaas Laurens Burman as Aloe vera on April 6, 1768 and by Philip Miller as Aloe barbadensis some ten days after Burman (LE, 1979). Considering this, the correct binomial name is Aloe vera (L.) Burm.f (Grindlay and Reynolds, 1986).

\section{Characteristics of Aloe Plants}

A. vera is a perennial succulent xerophyte green herb growing up to $100 \mathrm{~cm}$, with $15-30$ fleshy leaves per plant ranged in a rosette from a short stem that can reach $25 \mathrm{~cm}$ with age (Figure 1). The young leaves are central and straighter than the older, the peripheric ones, which are lower and more spreading. The leaves may be $0.5 \mathrm{~m}$ long and $10 \mathrm{~cm}$ wide at the base, with teeth like a saw along their margins (serrated margins). In young plants, the leaves and pups that arise from the base are bright green, with irregular whitish spots on both surfaces, adaxial, concave and abaxial, convex. With time, successive leaves have fewer spots and disappear in older leaves (Figure 2). The inflorescence is a raceme fixed on a peduncle $30-50 \mathrm{~cm}$ long, arising from the centre of the leaf rosette. The flowers are pendent, with a tubular yellow perianth approximately $2 \mathrm{~cm}$ long (Grindlay and Reynolds, 1986). Arbuscular mycorrhizal (AM) symbiosis has been shown to increase nutrient uptake and growth of Aloe(Pareek et al., 1999; Tawaraya et al., 2007).

Aloe arborescens Miller, native to central-southern Africa, is a traditional medicinal plant that is quite popular in South Africa, Asia, Russia, and Japan. A. arborescens is characterized by a central woody stem that can reach several meters. The branches have bushy shrubs, and the grey-green leaves are long, thin and spiny. The natural habitats of $A$. arborescens are mountainous regions of southern Africa (Salehi et al., 2018). A. arborescens is also grown as a source for medicinal, cosmetic, and food use in various countries (China, Israel, Italy, Japan, Crimean Peninsula). As pot plants, they reach only modest dimensions (Glatthaar-Saalmüller et al., 2015). The large colourful flower spikes are borne in profusion during May-July. The most common colour is deep orange, but there are also pure yellow forms, and an unusual bi-coloured form of deep orange (almost red) and yellow (Leistner, 2000; Heinrich, 2001). 
Puia A et al. (2021). Not Bot Horti Agrobo 49(2):12332

Figure 1. Aloe vera
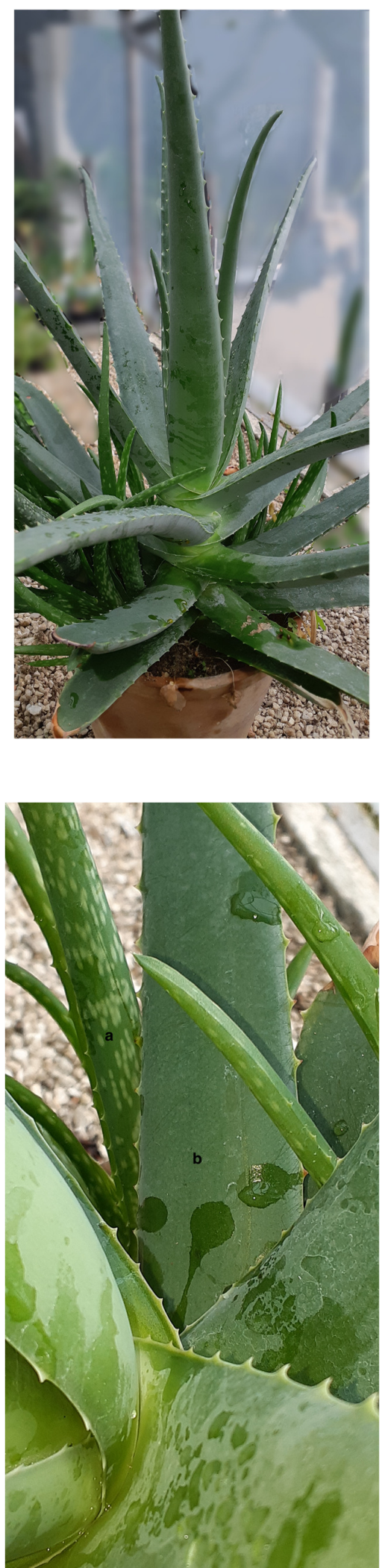

Figure 2. Aloe vera grown in the Green House ( $\mathrm{a}$ - young leaves, $\mathrm{b}$ - mature leaves) 
Aloe ferox Mill. (= A. candelabrum A. Berger), commonly known as the bitter Aloe or Cape aloe, is a polymorphic species indigenous to the Western Cape region of South Africa. It has a single, tree-like stem with succulent leaves protected by reddish spines; hence, the name ferrox (Latin for fierce). Six to twelve branches are present at $A$. candelabrum, and the flowers have their inner petals tipped with white. The flowers are carried in a large candelabra-like flower-head. There are usually between five and eight branches, each carrying a spikelike head of many flowers(Schmid et al., 1998).

\section{Phytochemical Constituents of Aloe Plants}

Aloe leaves, the most commonly used medicinal parts, can be divided into the following structural components: outer green epidermis, consisting of a thick cuticle and under a zone of chlorenchyma (1); outer pulp region, under the epidermis, containing vascular bundles with bitter sap (latex) that exudes from the leaves when they are cut (2); inner leaf pulp, containing large thin-walled parenchyma cells filled with the colorless mucilaginous gel (containing the aloe gel) (3) (Grindlay and Reynolds, 1986; Salehi et al., 2018). Description of the inner central part of the aloe leaf may sometimes be confusing, due to the different terms that are used interchangeably such as inner pulp, mucilage tissue, mucilaginous gel, mucilaginous jelly, inner gel and leaf parenchyma tissue. Technically, the term 'pulp' or 'parenchyma tissue' refers to the intact fleshy inner part of the leaf including the cell walls and organelles, while 'gel' or 'mucilage' refers to the viscous clear liquid within the parenchyma cells (Hamman, 2008). It is important to differentiate between the two medicinal components of $A$. vera leaves: gel and exudates.

The main classes of bioactive compounds differ among the three components. Thus, the outer green epidermis contains mostly anthraquinones, pre- anthraquinones and corresponding glycosides, while the outer pulp region consists of phenolic compounds (anthraquinones, pre-anthraquinones, flavonoids, chromones, anthrones, coumarins, and pyrones). The pulp is rich in acemannan and phenolic compounds. The Aloe gel from the inner leaf pulp also contains proteins, vitamins, minerals and enzymes.

Flowers of $A$. vera are a by-product with valuable bioactive compounds whose health benefits are only partially assessed. The flower can be considered as have three maturity stages: immature (1); mature (2); mature, with flowers buds opened (3)(Martínez-Sánchez et al., 2020).

Immature flowers present the highest content of phenolic and antioxidant capacity. As the flower develops the content of these compounds decreases, and the content of fatty acids increases. The last maturity stage has the lowest fatty acid content. These compounds have applications in the cosmetic, nutraceutical, pharmaceutical and food industries. The harvesting period may be chosen depending on the compound of interest and, by removing the flower, the energy consumption of flowers from the plant will be lower, thus favouring plant development(Martínez-Sánchez et al., 2020).

Zapata et al. (2013) noted that the leaf characteristics and gel chemical composition of eight Aloespecies studied in freshly harvested leaves in three different seasons within the Mediterranean climate have differences depending of species and harvest seasons.

The biological activities of the components are the result of a combined and synergistic action rather than the added effects of single substances (Dagne et al., 2005).

The anthraquinones contained by Aloe species are aloesaponarin, helminthosporin, aloechrysone, chrysophanol, aloesaponol, asphodelin and bianthracene (Salehi et al., 2018).

The anthrone class is represented by aloin (synonym - barbaloin), homonataloin and nataloin (Dagne et al., 2005). Aloin comprises two diastereomers: aloin A and aloin B. It is a C-glycoside that can be hydrolyzed in the gut to form aloe-emodin anthrone, which auto-oxidizes to quinone aloe-emodin. Emodin has numerous pharmacological effects. Both in vitro and in vivo studies have demonstrated anti-neoplastic, antiinflammatory, anti-angiogenic and toxicological potential for use in pharmacology (Hsu and Chung, 2012). 
Puia A et al. (2021). Not Bot Horti Agrobo 49(2):12332

Table 1. Aloe structural components with class, compounds, source and pharmacological activities (S. Choi and Chung, 2003; Dagne et al., 2005)

\begin{tabular}{|c|c|c|c|c|}
\hline $\begin{array}{l}\text { Aloe structural } \\
\text { components }\end{array}$ & Class & Compounds & Source & $\begin{array}{c}\text { Pharmacological } \\
\text { Activities }\end{array}$ \\
\hline \multirow{3}{*}{$\begin{array}{l}\text { The outer green } \\
\text { epidermis }\end{array}$} & Glycosides & & & \\
\hline & \multirow{3}{*}{$\begin{array}{c}\text { Anthraquinones } \\
\text { Pre-anthraquinones }\end{array}$} & $\begin{array}{l}\text { aloe-emodin } \\
\text { emodin }\end{array}$ & Aloe spp. & $\begin{array}{c}\text { Purgative, cell } \\
\text { proliferation, } \\
\text { anticancer,antiprotozoar, } \\
\text { antibacteria, antioxidant, } \\
\text { genotoxicity }\end{array}$ \\
\hline & & $\begin{array}{c}\text { aloetic acid } \\
\text { aloin } \\
\text { anthranol } \\
\text { isobarbaloin } \\
\text { ester of cinnamic acid }\end{array}$ & & \\
\hline \multirow{8}{*}{$\begin{array}{l}\text { The outer pulp } \\
\text { region }\end{array}$} & & barbaloin & Aloe spp. & Purgative \\
\hline & \multirow[t]{2}{*}{ Anthrones } & Aloe barbendol & Aloe barbadensis & \\
\hline & & Aloe-emodinanthrone & Aloe spp. & \\
\hline & Flavonoids & $\begin{array}{c}\text { Apigenin } \\
\text { Naringenin } \\
\text { Isovitexin }\end{array}$ & Aloe spp. & \\
\hline & Chromones & $\begin{array}{l}\text { Aloeresin C, D, E, F } \\
\text { Isoaloesin }\end{array}$ & $\begin{array}{l}\text { Aloe spp. } \\
\text { Cape aloe } \\
\text { Aloe vera }\end{array}$ & \\
\hline & Coumarins & $\begin{array}{c}\text { Feralolide } \\
\text { Dihydroisocoumarin } \\
\text { glucoside } \\
\end{array}$ & $\begin{array}{l}\text { Cape aloe } \\
\text { Aloe hildebrandtii }\end{array}$ & \\
\hline & Pyrones & $\begin{array}{c}\text { Aloenin } \\
\text { (Aloecarbonoside) } \\
\text { Aloenin acetal } \\
\text { Aloenin aglycone }\end{array}$ & $\begin{array}{l}\text { Aloe nyeriensis } \\
\text { Aloe arborescens }\end{array}$ & \\
\hline & Miscellaneous & Acemannan & Aloe vera & $\begin{array}{c}\text { Immunomodulation } \\
\text { Antimicrobiol effect } \\
\text { Antitumor }\end{array}$ \\
\hline \multirow{4}{*}{ The inner leaf pulp } & Proteins & $\begin{array}{c}\text { lectins } \\
\text { lectin-like substance }\end{array}$ & & \\
\hline & Vitamins & $\begin{array}{c}\text { B1 } \\
\text { B2 } \\
\text { B6 } \\
\text { C } \\
\beta \text {-carotene } \\
\text { choline } \\
\text { folic acid } \\
\alpha \text {-tocopherol } \\
\end{array}$ & & \\
\hline & Minerals & & & \\
\hline & Enzymes & $\begin{array}{c}\text { amylase } \\
\text { carboxypeptidase } \\
\text { catalase } \\
\text { cyclooxydase } \\
\text { lipase } \\
\text { oxidase }\end{array}$ & & \\
\hline
\end{tabular}


The chromones, an abundant phenolic class in leaves, comprise aloesin, aloeresin A and isomeric forms, from aloeresin $\mathrm{C}$ to aloeresin $\mathrm{F}$ (Cock, 2015).

Feralolide and dihydroisocoumarin glycoside are the coumarins contained in $A$. species leafs. Aloenin, aloenin aglycone, aloenin acetal and aloenin B are the pyrones identified in several Aloe species leaf exudates. The most common Aloe alkaloids are $\mathrm{N}$-methyltyramine and $\mathrm{O}, \mathrm{N}$-dimethyltyramine, while $\gamma$-coniceine is only present in a few species (Cock, 2015). Protocatechuic acid, methyl-p-coumarate and pluridone are benzene derivatives frequently identified in Aloes (Salehi et al., 2018).

Naringenin, apigenin, isovitexin and dihydro-isorhamnetin are the major flavonoids detected (Salehi et al., 2018). Phytosterols are represented by cholesterol, $\beta$-sitosterol, campesterol and lupeol together with their glucosides. Polysaccharides, the non-phenolic components, with acemannnan being the most important, are present in high abundance in Aloe gels. Acemannan, the main bioactive polysaccharide of $A$. vera, is a $\beta-(1,4)$ acetylated soluble polymannose (Liu et al., 2019). It is a storage polysaccharide in the protoplasts of parenchyma cells.

Aloe acemannan content depends greatly on the species and cultivation conditions. Irrigation influenced the amount of polysaccharides. The mannose content decreased with $41 \%$ in the case of water deficit. When the aloe was irrigated with seawater, $42 \%$ seawater stress treatment only reduced the polysaccharide concentration in the base leaves, without lowering the polysaccharide concentration in the upper and middle parts (Jiang et al., 2014). Considering the age of the plant, the acemannan level reached a peak in three-year-old $A$. vera plants and then decreased. In addition, increased light intensity resulted in higher acemannan concentrations in $A$. vera and $A$. arborescens (Ray and Aswatha, 2013).

Acemannan has been reported to have many pharmacological and biological applications in the medical field, such as oral, metabolic and cardiovascular diseases, oncology, dentistry and wound healing (Liu et al., 2019). Acemannan, when administered orally to mammals, inhibits cholesterol absorption and induces hypocholesterolemia. Parenterally, it induces macrophage activation and interleukin-1 release, stimulates bone marrow activity, promotes wound healing, and inhibits viral replication and tumour growth. This wide range of activities promotes the mannans to potential therapeutic agents and biological response modifiers (Tizard et al., 1989).

The largest vitamin contents are in Vitamin C, B1, B2, B6, B12 and E. Gels from Aloe species contain minerals, including Mg, Zn, Ca, K, Na, Fe, P, Mn, Cu, and Mo (Vogler and Ernst, 1999; S. Choi and Chung, 2003; Dagne et al., 2005; Hamman, 2008).

\section{Medicinal Use of Aloe Plants}

Gastrointestinal disorders, hepatoprotective action and beneficial effects against skin problems such as wounds, injuries, and infectious diseases are among the most frequently mentioned indications in traditional medicine in connection with Aloe species (Akaberi et al., 2016). Aloesp. dried juice is used traditionally in small doses as carminative and tonic and in larger doses, as a laxative and emmenagogue (Moein et al., 2017). The biological activity of many Aloe species covers a wide spectrum. Most of them come from traditional, folkloric use and some have been verified by in vitro or in vivo studies (Dehdari et al., 2018). The level of experimental or clinical confirmation is very variable, going from anecdotal mentioning to prospective, doubleblind clinical studies.

\section{Antimicrobial and antifungal activities}

The antimicrobial activity includes bacteria, fungi and viruses. "Smart" biohybrids containing $A$. vera with triiodide have excellent antifungal and promising antimicrobial activities, are cost-effective, ecofriendly and can be used against surgical site infections (SSI) and as disinfecting agents (Edis and Bloukh, 2020). 
In vitro activity assessment of Aloe barberae demonstrated antimicrobial effects on gram-positive (Bacillus subtilis and Staphylococcus aureus) and gram-negative bacteria (Escherichia coli and Klebsiella pneumoniae). Aloe sap extract is more effective than leaf extract (Ndhlala et al., 2009). Another study showed that $A$. vera juice has antimicrobial activity against $M$. smegmatis, $K$. pneumoniae, E. faecalis, M. luteus, $C$. albicans and B. sphericus, but has no effect on Staphylococcus aureus, Pseudomonas aeruginosa, Escherichia coli and Salmonella typhimurium (Alemdar and Agaoglu, 2009).

$A$. verahas better therapeutic, antibacterial and anti-inflammatory effects against staphylococcal pyoderma in dogs than gentamicin (Kamr et al., 2020).

A clinical study performed by Prueksrisakul et al. (2015) on healthy volunteers receiving $250 \mathrm{~mL}$ of $A$. vera gel extract daily demonstrated a significant decrease in the number of oral pathogenic bacteria.

Experimental studies have demonstrated that an aqueous suspension of $A$ loe polysaccharides can be used to control angular leaf spot disease (Xanthomonas fragariae), which acts both by its antimicrobial activity and by activating latent defence mechanisms in strawberry (Luiz et al., 2017).

In vitro antifungal effects of Aloe species extract have been demonstrated also in Candida albicans (Ndhlala et al., 2009). The purified Aloe protein fraction from the $A$. vera leaf gel had potent antifungal activity against Candida paraprilosis, Candida krusei and Candida albicans (Das et al., 2011).

A film containing Aloe vera used for coating sliced fruit prolonged the shelf-life of the merchandise by controlling fungal contamination(Benítez et al., 2015; Sánchez et al., 2020).

$A$ vera, $A$. ferox, $A$. mitriformis and $A$. saponaria have high antifungal activity against $B$. cinerea, $P$. digitatum, Penicillium expansum and $P$. italicum. Measured as a percentage of infected leaves, this antifungal activity was positively correlated with aloin content (Zapata et al., 2013).

A study performed by Nidiry et al. (2011) demonstrated that aloin and aloe-emodin are the active principles against two phytopathogenic fungi Colletotrichum gloeosporioides and Cladosporium cucumerinum.

Sydiskis et al. (1991) showed that aloe emodin inactivated herpes simplex type 1 and type 2, varicellazoster, pseudorabies and influenza but was not effective against adenovirus and rhinovirus. Electron microscopy demonstrated that the virucidal mechanism consisted of envelope disruption.

$A$. arborescens has been used for the treatment of upper respiratory tract infections in Central and Eastern European countries for many decades. In vitro study with a mixture containing $A$. arborescens extract showed a clear dose-dependent antiviral activity against human rhinovirus 14 and Coxsackievirus (both nonenveloped RNA viruses). Respiratory syncytial virus and parainfluenza virus (Paramyxoviridae) were poorly blocked by the test substance, while an adenovirus was not affected by the mixture (Glatthaar-Saalmüller et al., 2015).

Wound healing effect

Skin healing and tissue regeneration are among the most frequently used features in both traditional and modern medicine. Empirical observations were confirmed by in vitro studies, followed by experimental and clinical trials.

Liang et al. (2020) suggested that adding gel to the wound dressing could be a simple and standardized way to use $A$. vera. Inflammation is a normal component of healing, yet, the anti-inflammatory effects of Aloe sp. seem to boost tissue healing (Park et al., 2009). The in vitro study demonstrated anti-inflammatory effects of Aloesp., indirectly confirmed by the effect of aloe-emodin, comparable to that of kaempferol and quercetin (Ndhlala et al., 2009). The effect of G1G1M1DI2, a glycoprotein fraction isolated from $A$. vera, on cell migration was confirmed by the accelerated healing of a monolayer of human keratinocytes. It promoted the formation of epidermal tissue in raft culture. Thus, this glycoprotein fraction promotes wound healing by both cell proliferation and migration (Choi et al., 2001). Other healing effects include increased cell phagocytic effect, more rapid wound area contraction rate and collagen synthesis, all due to the mannose contained in $A$. vera. The polysaccharides present in $A$. verainduce fibroblast proliferation, hyaluronic acid and 
hydroxyproline production, which play an important role in extracellular matrix remodeling (Salehi et al., 2018). A. vera green-synthesized silver nanoparticles photobiomodulated by irradiation with laser led to an increase in cell migration in normal wounded and diabetic wounded fibroblast cells (Kumar et al., 2020). An experimental study in rats with eight Aloe species ( $A$. arborescens, $A$. brevifolia (Figure 3), A. eru, A. ferox, $A$. grandidentata, $A$. perfoliata, $A$. saponaria, and $A$. vera) demonstrated a significantly accelerated healing in the topical application of leaf methanol extracts on diabetic wounds (El Sayed et al., 2016). Oryan et al. (2016) showed that $A$. vera modulated inflammation, increased wound contraction and epithelialization, decreased scar tissue size, and increased alignment and organization of the regenerated scar tissue. The lesions also demonstrated improved modulus of elasticity, maximum load and ultimate strength. Oral administration of $A$. vera promotes healing by increasing collagen content and improving angiogenesis and chemotaxis in rats (Ali et al., 2020). Patients with thermal burns dressed with $A$. veragel showed advantages compared to those dressed with sulfadiazine regarding early wound epithelialization, earlier pain relief and cost-effectiveness (Shahzad and Ahmed, 2013). Aloesp. are also efficient in preventing and improving hypertrophic scars (Duansak et al., 2003; Surakunprapha et al., 2020). A. vera may have an anti-inflammatory effect in burn injuries due to the reduction in leukocyte adhesion and pro-inflammatory cytokines. A meta-analysis performed by Guo et al. (2016) concluded that $A$. vera may be used both as an alternative and integrative way to reduce symptom severity in the wound healing process at the mucocutaneous level.

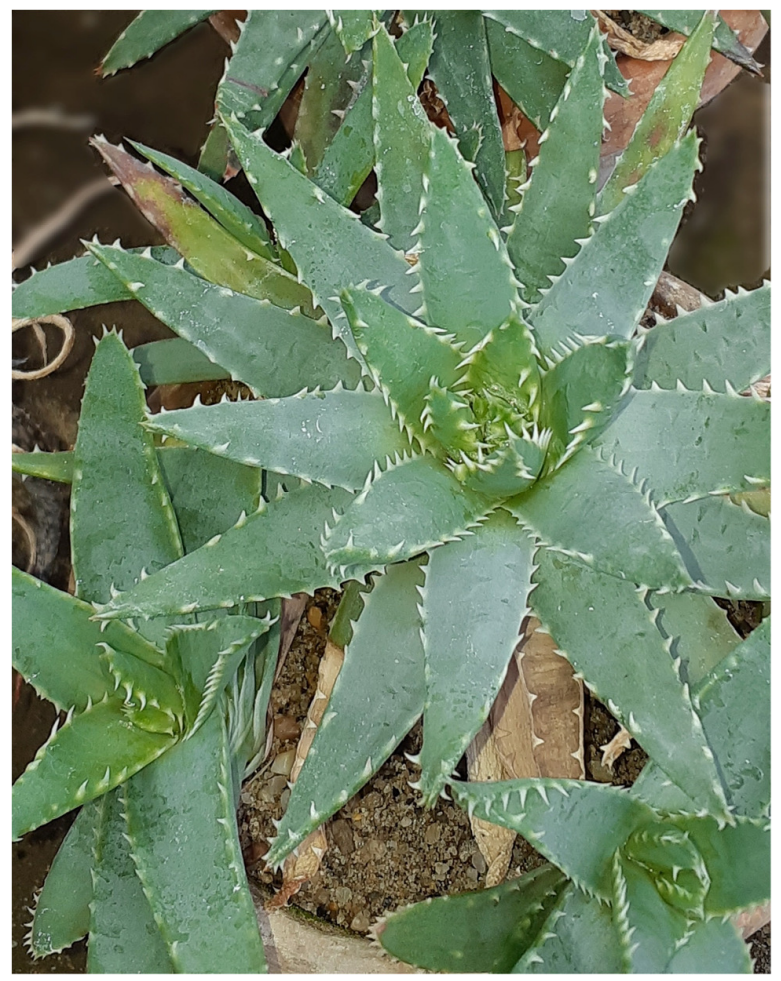

Figure 3. Aloe brevifolia

\section{Aloe effects on digestive system}

The favourable effects on the digestive system begin with the traditional use as a laxative and cover almost every aspect or organ. Significant antiulcer and gastroprotective activities were observed after the administration of Aloe-containing preparations (Akaberi et al., 2016; Eamlamnam et al., 2006). An interesting direction was provided by a study that noted that the $A$. vera gel has antibacterial properties against both susceptible and resistant Helicobacter pylori strains. Thus, a combination of $A$. vera gel with antibiotics may improve the results of $H$. pylorieradication (Cellini et al., 2014). A study on rats that deal with the effect of $A$. 
vera on gastric microcirculatory changes, cytokine levels and gastric ulcer healing showed that $A$. vera treatment reduced leukocyte adherence and TNF-alpha levels, elevated IL-10 levels and promoted gastric ulcer healing (Eamlamnam et al., 2006).

A study with a $A$. ferox extract on constipated rats led to improved intestinal motility, increased fecal volume and normalized body weight, confirming the empiric use as a laxative in South Africa (Wintola et al., 2010). A similar effect is targeted in sheep diets containing $A$. vera extract to reduce enteric methane emission and boost productivity (Akanmu et al., 2020). A recent study has confirmed that acemannan has the advantage of inducing intestinal growth in bacteria such as Bifidobacterium and Lactobacillus (Quezada et al., 2017). A. vera gel had a dose-dependent inhibitory effect on reactive oxygen metabolite production in incubated colorectal mucosal biopsies, which indicated a therapeutic effect in inflammatory bowel disease (Langmead et al., 2004). Aloe extract and a number of its compounds have been shown to ameliorate inflammation and improve clinical and histopathological colitis symptoms in animal models (Akaberi et al., 2016). Any prolonged treatment for chronic inflammatory bowel disease should maintain a high awareness of cancer risk (Harris et al., 2020).

Prospective, randomized, double-blind, placebo-controlled trials in proctology consisted of the application of $A$. vera cream on the surgical site. The results were similar and demonstrated that the treatment is effective in reducing postoperative pain both at rest and during defecation, healing time, and analgesic requirements (Gaj and Crispino, 2009; Eshghi et al., 2010).

The bitter latex of Aloe ferox is used as a laxative in Africa and Europe and is considered to have tonic, antioxidant, anti-inflammatory, antimicrobial and anticancer properties (Chen et al., 2012).

\section{Hepatoprotective effects}

$A$. vera and $A$. arborescens have hepatoprotective activities (Singab et al., 2015). Thus, polysaccharides exert a protective effect against chronic alcohol-induced liver injury (Cui et al., 2014), toxic solvents such as carbon tetrachloride (Chandan et al., 2007), and aflatoxins (Cui et al., 2017). The hepatoprotective effect appears to be associated with antioxidant capacity and the ability to accelerate lipolysis and inhibit inflammatory response, improve excretory capacity and stimulate bile flow secretion. However, its use in gallbladder conditions that are at risk for carcinogenesis should be discouraged (Puia and Puia, 2013).

Aloe may be used for intestinal drug absorption enhancement in drugs with low bioavailability due to extensive efflux (Josias et al., 2013).

\section{Anticancer activity}

A review performed by Singab et al. (2015) mentioned several studies with findings about the effectiveness of Aloesp. on various cancers affecting several organs, including the colon, liver, duodenum, skin, pancreas, intestine, lungs and kidneys. Aloe is thought to be a potential agent for the treatment of gastrointestinal cancers. Qin et al. (2006) noted that the inhibitory effect of aloe-emodin on the proliferation and migration of gastric tumour cell lines is dose-dependent. Pan et al. (2013) showed that aloin inhibits tumour angiogenesis and growth by blocking STAT3 activation. Aloe-emodin and emodin demonstrated anticancer activities in the human gastric cancer MKN45 cell line (Chihara et al., 2015). Emodin also induces apoptosis and cell death in human lung squamous carcinoma cells in vitro (Lee et al., 2001). Aloin can be used to radio-sensitize HeLaS3 human cervical carcinoma cells, thus reducing the necessary doses for radiotherapy from 3.4 to 2 Gy (Nićiforović et al., 2007). Paraneoplastic venous thrombosis affects many patients. Fan et al. (2018) demonstrated in vitro that protein and phenolic extracts of four Aloe species have good thrombolytic and fibrinolytic activities. Adding this clot lytic quality to the known anticancer effects may open a new direction in the use of Aloesp. in oncological treatment (Fan et al., 2018). 
Antioxidant activity

In vitro studies have demonstrated that $A$. vera extracts from both leaves and flowers are good natural antioxidant sources (López et al., 2013). A study performed on several Aloe sp. concluded that the most active antioxidant may be found in $A$. pillansii along with $A$. broomii and $A$. spinosissima, comparable to the better known $A$. arborescens and $A$. vera (Sazhina et al., 2016). A study on healthy volunteers receiving $250 \mathrm{~mL}$ of $A$. veragel extract daily demonstrated a significant increase in the plasma total antioxidant capacity (TAC)(Prueksrisakul et al., 2015).

In a study performed in India on plants harvested from various regions, $A$. vera extracts from colder climatic regions showed good antiplasmodial activity. There was a significant correlation between the quantities of aloin and aloe-emodin and the antiplasmodial effect (Kumar et al., 2020). Homonataloin, belonging to the anthrone group, seems to be the most efficient component against chloroquineresistant Plasmodium falciparum strains (van Zyl et al., 2002).

Maphosa et al. (2010) provided evidence that $A$. ferox extract has in-vitro anthelminthic activity, thus encouraging use in the treatment of GI helminthosis.

\section{Antidiabetic effects}

The empirical use of Aloe sp. as an antidiabetic has been supported by several studies (Grindlay and Reynolds, 1986). A study by Froldi et al. (2019) demonstrated that both the methanolic and the hydroalcoholic $A$. arborescens extracts led to the inhibition of glycation and free-radical persistence, without any cytotoxic activity, thus supporting the traditional use of $A$. arborescens leaf extracts against hyperglycemic conditions. Five phytosterols evaluated for their anti-hyperglycemic effects in type 2 diabetic mice led to a decrease in fasting blood glucose levels between $28 \%$ and $64 \%$ compared to the control levels (Tanaka et al., 2006). A double-blind randomized controlled trial on 72 patients with pre-diabetes symptoms demonstrated that fasting blood glucose and HbA1C levels improved after 8 weeks (Alinejad-Mofrad et al., 2015). In a randomized double-blind placebo-controlled clinical trial, Huseini et al. (2012) demonstrated that $A$. vera gel lowered fasting blood glucose and HbAlc levels significantly without affecting any liver/kidney function tests.

\section{Antihyperlipidic effects}

In an experimental study performed by Dana et al. (2012) significant differences were observed between cholesterol levels in rats fed a high-cholesterol diet combined with $A$. vera and a high-cholesterol diet alone. The formation of fatty streaks in the aorta was also significantly lower in the same animals under the influence of diet with $A$. vera.

A clinical study showed the effectiveness of $A$. vera in improving total cholesterol, LDL-C, HDL-C and triglycerides after 4- 8 weeks of intake (Alinejad-Mofrad et al., 2015).

Huseini et al. (2012) noted that Aloegel has a favourable effect on total cholesterol and LDL levels and no adverse effects, thus promoting it as a safe anti-hypercholesterolemic agent for hyperlipidemic patients.

The research of Misawa et al. (2012) have shown that $A$. vera gel powder combined with a high-fat diet induces in rats only a modest decrease of body weight but, much more important, reduces significantly subcutaneous, visceral and total body fat. In an experimental study meant to decipher the anti-obesity mechanism of $A$. vera gel extract Tada et al. (2020) showed that brown adipose tissue activation contributes to weight loss.

\section{Other favourable effects}

Placebo-controlled studies have shown that the consumption of mannans improves cognitive performance in middle-aged patients with mental fatigue. Improvements in memory performance following mannan intake were independent of changes in blood glucose levels (Best et al., 2015).

The ameliorating effect of aqueous extract of $A$. vera leaves against cartap and malathion toxicity could be used to protect non-target animals from the adverse effects of pesticides (Gupta et al., 2020). 
In cosmetology, Aloesp. are used in toothpaste, creams, shampoos and soap production. Industrial applications as bitter agents or consistence modifiers include beverages, ice cream or food supplements.

A panel of experts established that Aloe is not toxic in experimental acute oral studies but can cause significant sperm damage, be abortifacient or produce skeletal abnormalities. Aloin had no carcinogenic effects on mice. Case reports in humans included acute eczema, contact urticaria, and dermatitis, but no phototoxicity in topic use (Andersen, 2007).

A major obstacle in introducing A. spp derived products on a large scale in medicine is the lack of standardization regarding the components and their concentration (Moein et al., 2017).

\section{Conclusions}

Many species of the Aloe genus have been in use for a long time in folk medicine and, more recently, as components of food and beverages. Its adaptability led to a worldwide spontaneous or cultivated growth that made Aloe available at a reasonable cost. Traditional Aloe remedies cover most human diseases; however, in order to gain legitimacy, the derived drugs must have a well-established composition, with thoroughly investigated adverse effects and conventional drug interactions.

\section{Authors' Contributions}

Conceptualization: AP, CP, MF; Data curation: EM, FG and AF; Supervision: CP; Validation: AP, CP, EM, FG, AF, MF; Visualization: AP, CP, EM, FG, AF, MF; Writing - original draft: AP and CP; Writing - review and editing: AP, CP, EM, FG, AF, MF. All authors read and approved the final manuscript.

\section{Acknowledgements}

This research received no specific grant from any funding agency in the public, commercial, or not-forprofit sectors.

\section{Conflict of Interests}

The authors declare that there are no conflicts of interest related to this article.

\section{References}

Akaberi M, Sobhani Z, Javadi B, Sahebkar A, Emami SA (2016). Therapeutic effects of Aloe spp. in traditional and modern medicine: A review. Biomedicine and Pharmacotherapy 84:759-772. https://doi.org/10.1016/j.biopha.2016.09.096

Akanmu AM, Hassen A, Adejoro FA (2020). Haematology and serum biochemical indices of lambs supplemented with Moringa oleifera, Jatropha curcas and Aloe veraleaf extract as anti-methanogenic additives. Antibiotics 14(9):601. https://doi.org/10.3390/antibiotics9090601

Alemdar S, Agaoglu S (2009). Investigation of in vitro antimicrobial activity of Aloe vera juice. Journal of Animal and Veterinary Advances 8(1):99-102. 
Ali F, Wajid N, Sarwar MG, Qazi AM (2020). Oral administration of Aloe vera ameliorates wound healing through improved angiogenesis and chemotaxis in Sprague Dawley rats. Current Pharmaceutical Biotechnology. https://doi.org/10.2174/1389201021999201001204345

Alinejad-Mofrad S, Foadoddini M, Saadatjoo SA, Shayesteh M (2015). Improvement of glucose and lipid profile status with Aloe vera in pre-diabetic subjects: A randomized controlled-trial. Journal of Diabetes and Metabolic Disorders 14(22). https://doi.org/10.1186/s40200-015-0137-2

Andersen FA (2007). Final report on the safety assessment of Aloe andongensis extract, Aloe andongensis leaf juice, Aloe arborescens leaf extract, Aloe arborescens leaf juice, Aloe arborescens leaf protoplasts, Aloe barbadensis flower extract, Aloe barbadensis leaf, aloe bar. International Journal of Toxicology 26(2):1-50. https://doi.org/10.1080/10915810701351186

Benítez S, Achaerandio I, Pujolà M, Sepulcre F (2015). Aloe vera as an alternative to traditional edible coatings used in fresh-cut fruits: A case of study with kiwifruit slices. LWT - Food Science and Technology 61:184-193. https://doi.org/10.1016/j.lwt.2014.11.036

Best T, Howe P, Bryan J, Buckley J, Scholey A (2015). Acute effects of a dietary non-starch polysaccharide supplement on cognitive performance in healthy middle-aged adults. Nutritional Neuroscience 18(2):76-86. https://doi.org/10.1179/1476830513Y.0000000101

Brandham PE, Carter S, Reynolds T (1994). A multidisciplinary study of relationships among the cremnophilous aloes of northeastern Africa. Kew Bulletin 49(3):415-428. https://doi.org/10.2307/4114465

Cellini L, Di Bartolomeo S, Di Campli E, Genovese S, Locatelli M, Di Giulio M (2014). In vitro activity of Aloe vera inner gel against Helicobacter pylori strains. Letters in Applied Microbiology 59(1):43-48. https://doi.org/10.1111/lam.12241

Chandan BK, Saxena AK, Shukla S, Sharma N, Gupta DK, Suri KA, Suri J, Bhadauria M, Singh B (2007). Hepatoprotective potential of Aloe barbadensis Mill. against carbon tetrachloride induced hepatotoxicity. Journal of Ethnopharmacology 111(3):560-566. https://doi.org/10.1016/j.jep.2007.01.008

Chen W, Van Wyk BE, Vermaak I, Viljoen AM (2012). Cape aloes - A review of the phytochemistry, pharmacology and commercialisation of Aloe ferox. Phytochemistry Letters 5(1):1-12. https://doi.org/10.1016/j.phytol.2011.09.001

Chihara T, Shimpo K, Beppu H, Yamamoto N, Kaneko T, Wakamatsu K, Sonoda S (2015). Effects of aloe-emodin and emodin on proliferation of the MKN45 human gastric cancer cell line. Asian Pacific Journal of Cancer Prevention 16(9):3887-3891. https://doi.org/10.7314/APJCP.2015.16.9.3887

Choi S, Chung MH (2003). A review on the relationship between Aloe vera components and their biologic effects. In: Seminars in Integrative Medicine 1(1):53-62. https://doi.org/10.1016/S1543-1150(03)00005-X

Choi SW, Son BW, Son YS, Park YI, Lee SK, Chung MH (2001). The wound-healing effect of a glycoprotein fraction isolated from Aloe vera. British Journal of Dermatology 145:535-545. https://doi.org/10.1046/j.13652133.2001.04410.x

Cock IE (2015). The genus Aloe: Phytochemistry and therapeutic uses including treatments for gastrointestinal conditions and chronic inflammation. Progress in Drug Research. https://doi.org/10.1007/978-3-0348-0927$6 \_6$

Cui Y, Cheng Y, Guo Y, Xie Y, Yao W, Zhang W, Qian H (2017). Evaluating the hepatoprotective efficacy of Aloe vera polysaccharides against subchronic exposure of aflatoxins B1. Journal of the Taiwan Institute of Chemical Engineers 76:10-17. https://doi.org/10.1016/j.jtice.2017.03.040

Cui Y, Ye Q, Wang H, Li Y, Yao W, Qian H (2014). Hepatoprotective potential of Aloe vera polysaccharides against chronic alcohol-induced hepatotoxicity in mice. Journal of the Science of Food and Agriculture 94(9):1764-1771. https://doi.org/10.1002/jsfa.6489

Dagne E, Bisrat D, Viljoen A, Van Wyk B-E (2005). Chemistry of Aloespecies. Current Organic Chemistry 4:1055-1078. https://doi.org/10.2174/1385272003375932

Dana N, Javanmard SH, Asgary S, Asnaashari H, Abdian N (2012). The effect of Aloe vera leaf gel on fatty streak formation in hypercholesterolemic rabbits. Journal of Research in Medical Sciences 17(5):439-442.

Das S, Mishra B, Gill K, Ashraf MS, Singh AK, Sinha M, ... Dey S (2011). Isolation and characterization of novel protein with anti-fungal and anti-inflammatory properties from Aloe vera leaf gel. International Journal of Biological Macromolecules 48(1):38-43. https://doi.org/10.1016/j.ijbiomac.2010.09.010 
Dehdari S, Hajimehdipoor H, Esmaeili S, Choopani R, Mortazavi SA (2018). Traditional and modern aspects of hemorrhoid treatment in Iran: a review. Journal of Integrative Medicine 16(2):90-98. https://doi.org/10.1016/j.joim.2018.01.002

Duansak D, Somboonwong J, Patumraj S (2003). Effects of Aloe vera on leukocyte adhesion and TNF- $\alpha$ and IL-6 levels in burn wounded rats. Clinical Hemorheology and Microcirculation.

Eamlamnam K, Patumraj S, Visedopas N, Thong-Ngam D (2006). Effects of Aloe vera and sucralfate on gastric microcirculatory changes, cytokine levels and gastric ulcer healing in rats. World Journal of Gastroenterology 12(13):2034-2039. https://doi.org/10.3748/wjg.v12.i13.2034

Edis Z, Bloukh SH (2020). Facile synthesis of antimicrobial aloe vera-"smart" triiodide-PVP biomaterials. Biomimetics 5(3):45. https://doi.org/10.3390/BIOMIMETICS5030045

El Sayed AM, Ezzat SM, El Naggar MM, El Hawary SS (2016). In vivo diabetic wound healing effect and HPLC-DADESI-MS/MS profiling of the methanol extracts of eight Aloe species. Revista Brasileira de Farmacognosia 26:352362. https://doi.org/10.1016/j.bjp.2016.01.009

Eshghi F, Hosseinimehr SJ, Rahmani N, Khademloo M, Norozi MS, Hojati O (2010). Effects of Aloe vera cream on posthemorrhoidectomy pain and wound healing: Results of a randomized, blind, placebo-control study. Journal of Alternative and Complementary Medicine 16(6):647-650. https://doi.org/10.1089/acm.2009.0428

Fan JJ, Li CH, Hu YJ, Chen H, Yang FQ (2018). Comparative assessment of in vitro thrombolytic and fibrinolysis activity of four Aloe species and analysis of their phenolic compounds by LC-MS. South African Journal of Botany 119:325-334. https://doi.org/10.1016/j.sajb.2018.10.001

Froldi G, Baronchelli F, Marin E, Grison M (2019). Antiglycation activity and HT-29 cellular uptake of aloe-emodin, aloin, and aloe arborescens leaf extracts. Molecules 24(11):2128. https://doi.org/10.3390/molecules24112128

Gaj F, Crispino P (2009). Chirurgia proctologica: Vantaggi derivanti dall'uso di un detergente innovativo nel postoperatorio. Clinica Terapeutica 160(3):211-213.

Glatthaar-Saalmüller B, Fal AM, Schönknecht K, Conrad F, Sievers H, Saalmüller A (2015). Antiviral activity of an aqueous extract derived from Aloe arborescens Mill. against a broad panel of viruses causing infections of the upper respiratory tract. Phytomedicine 22(10):911-920. https://doi.org/10.1016/j.phymed.2015.06.006

Grace OM, Simmonds MSJ, Smith GF, Van Wyk AE (2009). Documented utility and biocultural value of Aloe L. (Asphodelaceae): A review. Economic Botany 63:167-178. https://doi.org/10.1007/s12231-009-9082-7

Grindlay D, Reynolds T (1986). The Aloe vera phenomenon: A review of the properties and modern uses of the leaf parenchyma gel. Journal of Ethnopharmacology 16(2-3):117-151. https://doi.org/10.1016/03788741(86)90085-1

Guo X, Mei N (2016). Aloe vera: A review of toxicity and adverse clinical effects. Journal of Environmental Science and Health - Part C Environmental Carcinogenesis and Ecotoxicology Reviews 34(2):77-96. https://doi.org/10.1080/10590501.2016.1166826

Gupta VK, Kumar A, Pereira M de L, Siddiqi NJ, Sharma B (2020). Anti-inflammatory and antioxidative potential of Aloe vera on the cartap and malathion mediated toxicity in wistar rats. International Journal of Environmental Research and Public Health 17(14):5177. https://doi.org/10.3390/ijerph17145177

Hamman JH (2008). Composition and applications of Aloe vera leaf gel. Molecules 13(8):1599-1616. https://doi.org/10.3390/molecules 13081599

Harris M, Brekke M, Dinant GJ, Esteva M, Hoffman R, Marzo-Castillejo M ... Taylor G (2020). Primary care practitioners' diagnostic action when the patient may have cancer: an exploratory vignette study in 20 European countries. BMJ Open 10(10):e035678. https://doi.org/10.1136/bmjopen-2019-035678

Heinrich M (2001). People's plants. Journal of Ethnopharmacology 1315 https://doi.org/10.1016/s03788741(00)00308-1

Hsu SC, Chung JG (2012). Anticancer potential of emodin. BioMedicine (Netherlands) 2(3):108-116. https://doi.org/10.1016/j.biomed.2012.03.003

Huseini HF, Kianbakht S, Hajiaghaee R, Dabaghian FH (2012). Anti-hyperglycemic and anti-hypercholesterolemic effects of Aloe vera leaf gel in hyperlipidemic type 2 diabetic patients: A randomized double-blind placebocontrolled clinical trial. Planta Medica 78(4):311-316. https://doi.org/10.1055/s-0031-1280474

Jansisyanont P, Tiyapongprapan S, Chuenchompoonut V, Sangvanich P, Thunyakitpisal P (2016). The effect of acemannan sponges in post-extraction socket healing: A randomized trial. Journal of Oral and Maxillofacial Surgery, Medicine, and Pathology 28:105-110. https://doi.org/10.1016/j.ajoms.2015.07.006 
Jiang CQ, Quan LT, Shi F, Yang N, Wang CH, Yin XM, Zheng QS (2014). Distribution of mineral nutrients and active ingredients in Aloe vera irrigated with diluted seawater. Pedosphere 24:722-730. https://doi.org/10.1016/S10020160(14)60059-X

Josias H, Carien B, Alvaro V (2013). Modulation of drug efflux by aloe materials: An in vitro investigation across rat intestinal tissue. Pharmacognosy Magazine 9(1):S44-8. https://doi.org/10.4103/0973-1296.117864

Kamr A, Arbaga A, El-Bahrawy A, Elsify A, Khaled H, Hassan H (2020). The therapeutic efficacy of Aloe vera gel ointment on staphylococcal pyoderma in dogs. Veterinary World 13(11):2371-2380. https://doi.org/10.14202/VETWORLD.2020.2371-2380

King EG, Stanton ML (2008). Facilitative effects of aloe shrubs on grass establishment, growth, and reproduction in degraded Kenyan rangelands: Implications for restoration. Restoration Ecology 16:464-474. https://doi.org/10.1111/j.1526-100X.2007.00310.x

Kumar SSD, Houreld NN, Abrahamse H (2020). Selective laser efficiency of green-synthesized silver nanoparticles by aloe arborescens and its wound healing activities in normal wounded and diabetic wounded fibroblast cells: In vitro studies. International Journal of Nanomedicine 16(15):6855-6870. https://doi.org/10.2147/IJN.S257204

Langmead L, Makins RJ, Rampton DS (2004). Anti-inflammatory effects of Aloe veragel in human colorectal mucosa in vitro. Alimentary Pharmacology and Therapeutics 19(5):521-527. https://doi.org/10.1111/j.13652036.2004.01874.x

Le N (1979). In defense of the name Aloe vera. The Cactus and Succulent Journal of Great Britain 41:29-30.

Lee HZ, Hsu SL, Liu MC, Wu CH (2001). Effects and mechanisms of aloe-emodin on cell death in human lung squamous cell carcinoma. European Journal of Pharmacology 431(3):287-295. https://doi.org/10.1016/S00142999(01)01467-4

Leistner OA (2000). Seed plants of southern Africa: families and genera. In: Seed plants of southern Africa: families and genera.

Liang J, Cui L, Li J, Guan S, Zhang K, Li J (2020). Aloe vera: a medicinal plant used in skin wound healing. Tissue Engineering Part B: Reviews. https://doi.org/10.1089/ten.teb.2020.0236

Liu C, Cui Y, Pi F, Cheng Y, Guo Y, Qian H (2019). Extraction, purification, structural characteristics, biological activities and pharmacological applications of acemannan, a polysaccharide from Aloe vera: A review. Molecules 24(8):1554. https://doi.org/10.3390/molecules24081554

López A, De Tangil MS, Vega-Orellana O, Ramírez AS, Rico M (2013). Phenolic constituents, antioxidant and preliminary antimycoplasmic activities of leaf skin and flowers of Aloe vera (L.) Burm. f. (syn. A. barbadensis Mill.) from the Canary Islands (Spain). Molecules 18(5):4942-4954. https://doi.org/10.3390/molecules 18054942

Luiz C, da Rocha Neto AC, Franco PO, Di Piero RM (2017). Emulsions of essential oils and aloe polysaccharides: Antimicrobial activity and resistance inducer potential against Xanthomonas fragariae. Tropical Plant Pathology 42:370-381. https://doi.org/10.1007/s40858-017-0153-5

Maphosa V, Masika PJ, Bizimenyera ES, EloffJN (2010). In-vitro anthelminthic activity of crude aqueous extracts of Aloe ferox, Leonotis leonurus and Elephantorrhiza elephantina against Haemonchus contortus. Tropical Animal Health and Production 42:301-307. https://doi.org/10.1007/s11250-009-9421-9

Martínez-Sánchez A, López-Cañavate ME, Guirao-Martínez J, Roca MJ, Aguayo E (2020). Aloe vera flowers, a byproduct with great potential and wide application, depending on maturity stage. Foods 9(11):1542. https://doi.org/10.3390/foods9111542

Misawa E, Tanaka M, Nabeshima K, Nomaguchi K, Yamada M, Toida T, Iwatsuki K (2012). Administration of dried Aloe vera gel powder reduced body fat mass in diet-induced obesity (DIO) rats. Journal of Nutritional Science and Vitaminology 58(3):195-201. https://doi.org/10.3177/jnsv.58.195

Moein E, Hajimehdipoor H, Toliyat T, Choopani R, Hamzeloo-Moghadam M (2017). Formulation of an aloe-based product according to Iranian traditional medicine and development of its analysis method. DARU, Journal of Pharmaceutical Sciences 25(1):19. https://doi.org/10.1186/s40199-017-0185-X

Mukesh S, Patil MB, Shalini S, Vishnu B (2010). Aloe vera: Plant of immortality. International Journal of Pharma Sciences and Research 1(1):7-10.

Ndhlala AR, Amoo SO, Stafford GI, Finnie JF, Van Staden J (2009). Antimicrobial, anti-inflammatory and mutagenic investigation of the South African tree aloe (Aloe barberae). Journal of Ethnopharmacology 124(3):404-408. https://doi.org/10.1016/j.jep.2009.05.037 
Nićiforović A, Adžić M, Spasić SD, Radojčić MB (2007). Antitumor effects of a natural anthracycline analog (aloin) involve altered activity of antioxidant enzymes in HeLaS3 cells. Cancer Biology and Therapy 6:1211-1216. https://doi.org/10.4161/cbt.6.8.4383

Nidiry ESJ, Ganeshan G, Lokesha AN (2011). Antifungal activity of some extractives and constituents of Aloe vera. Research Journal of Medicinal Plant 5:196-200. https://doi.org/10.3923/rjmp.2011.196.200

Oryan A, Mohammadalipour A, Moshiri A, Tabandeh MR (2016). Topical application of Aloe vera accelerated wound healing, modeling, and remodeling. Annals of Plastic Surgery 77:37-46. https://doi.org/10.1097/SAP.0000000000000239

Pan Q, Pan H, Lou H, Xu Y, Tian L (2013). Inhibition of the angiogenesis and growth of Aloin in human colorectal cancer in vitro and in vivo. Cancer Cell International 13(1):69. https://doi.org/10.1186/1475-2867-13-69

Pareek OP, Sharma BD, Nath V, Singh RS, Bhargava R (1999). Effect of nitrogen and phosphorus fertilizers and organic manure on growth and yield of Indian Aloe (Aloe barbadensis Mill.). Annals of Arid Zone 38(1):85-86.

Park MY, Kwon HJ, Sung MK (2009). Evaluation of aloin and aloe-emodin as anti-inflammatory agents in aloe by using murine macrophages. Bioscience, Biotechnology and Biochemistry 73(4):828-832. https://doi.org/10.1271/bbb.80714

Prabakaran S, Rajan M, Lv C, Meng G (2020). Lanthanides-substituted hydroxyapatite/Aloe vera composite coated titanium plate for bone tissue regeneration. International Journal of Nanomedicine 27(15):8261-8279. https://doi.org/10.2147/IJN.S267632

Prueksrisakul T, Chantarangsu S, Thunyakitpisal P (2015). Effect of daily drinking of Aloe veragel extract on plasma total antioxidant capacity and oral pathogenic bacteria in healthy volunteer: A short-term study. Journal of Complementary and Integrative Medicine 12:159-164. https://doi.org/10.1515/jcim-2014-0060

Puia IC, Puia A (2013). Porcelain gallbladder and cancer - an association to be revised. Journal of Gastrointestinal and Liver Diseases 22(3):358-359.

Quezada MP, Salinas C, Gotteland M, Cardemil L (2017). Acemannan and fructans from Aloe vera (Aloe barbadensis Miller) plants as novel prebiotics. Journal of Agricultural and Food Chemistry 65(46):10029-10039. https://doi.org/10.1021/acs.jafc.7b04100

Ray A, Aswatha SM (2013). An analysis of the influence of growth periods on physical appearance, and acemannan and elemental distribution of Aloe vera L. gel. Industrial Crops and Products 48:36-42. https://doi.org/10.1016/j.indcrop.2013.03.024

Riley HP (1959). Polyploidy in South African species of Aloe. American Journal of Botany 46(2):126-129. https://doi.org/10.2307/2439468

Salehi B, Albayrak S, Antolak H, Kręgiel D, Pawlikowska E, Sharifi-Rad M, ... Sharifi-Rad J (2018). Aloe genus plants: From farm to food applications and phytopharmacotherapy. International Journal of Molecular Sciences 19(9):2843. https://doi.org/10.3390/ijms19092843

Sánchez JT, García AV, Martínez-Abad A, Vilaplana F, Jiménez A, Garrigós MC (2020). Physicochemical and functional properties of active fish gelatin-based edible films added with Aloe vera gel. Foods 9(9):1248. https://doi.org/10.3390/foods9091248

Sánchez M, González-Burgos E, Iglesias I, Gómez-Serranillos MP (2020). Pharmacological update properties of Aloe vera and its major active constituents. Molecules 25(6):1324. https://doi.org/10.3390/molecules25061324

Sazhina NN, Lapshin PV, Zagoskina NV, Misin VM (2016). Comparative study of antioxidant properties of extracts of various Aloe species. Russian Journal of Bioorganic Chemistry 42:735-740. https://doi.org/10.1134/S106816201607013X

Schmid R, van Wyk B-E, van Oudtshoorn B, Gericke N (1998). Medicinal plants of South Africa. Taxon. https://doi.org/10.2307/1223627

Shahzad MN, Ahmed N (2013). Effectiveness of Aloe vera gel compared with 1\% silver sulphadiazine cream as burn wound dressing in second degree burns. Journal of the Pakistan Medical Association 63(2):225-230.

Singab ANB, El-Hefnawy HM, Esmat A, Gad HA, Nazeam JA (2015). A systemic review on aloe arborescens pharmacological profile: biological activities and pilot clinical trials. Phytotherapy Research 29(12):1858-1867. https://doi.org/10.1002/ptr.5483

Surakunprapha P, Winaikosol K, Chowchuen B, Punyavong P, Jenwitheesuk K, Jenwitheesuk K (2020). A prospective randomized double-blind study of silicone gel plus herbal extracts versus placebo in pre-sternal hypertrophic scar prevention and amelioration. Heliyon 6(5):e03883. https://doi.org/10.1016/j.heliyon.2020.e03883 
Sydiskis RJ, Owen DG, Lohr JL, Rosler KHA, Blomster RN (1991). Inactivation of enveloped viruses by anthraquinones extracted from plants. Antimicrobial Agents and Chemotherapy 35(12):2463-2466. https://doi.org/10.1128/AAC.35.12.2463

Tada A, Misawa E, Tanaka M, Saito M, Nabeshima K, Yamauchi K, ... Kawada T (2020). Investigating anti-obesity effects by oral administration of Aloe vera gel extract (AVGE): Possible involvement in activation of brown adipose tissue (BAT). Journal of Nutritional Science and Vitaminology 66(2):176-184. https://doi.org/10.3177/jnsv.66.176

Tanaka M, Misawa E, Ito Y, Habara N, Nomaguchi K, Yamada M, ... Higuchi R (2006). Identification of five phytosterols from Aloe vera gel as anti-diabetic compounds. Biological and Pharmaceutical Bulletin 29(7):1418-1422. https://doi.org/10.1248/bpb.29.1418

Tawaraya K, Turjaman M, Ekamawanti HA (2007). Effect of arbuscular mycorrhizal colonization on nitrogen and phosphorus uptake and growth of Aloe vera L. HortScience. https://doi.org/10.21273/hortsci.42.7.1737

Tizard IR, Carpenter RH, McAnalley BH, Kemp MC (1989). The biological activities of mannans and related complex carbohydrates. Molecular Biotherapy 1:290-296.

van Zyl RL, Viljoen AM, Jäger AK (2002). In vitro activity of Aloe extracts against Plasmodium falciparum. South African Journal of Botany 68:106-110. https://doi.org/10.1016/s0254-6299(16)30465-3

Vogler BK, Ernst E (1999). Aloe vera: A systematic review of its clinical effectiveness. British Journal of General Practice.

Wintola OA, Sunmonu TO, Afolayan AJ (2010). The effect of Aloe ferox Mill. In the treatment of loperamide-induced constipation in Wistar rats. BMC Gastroenterology 19(10):95. https://doi.org/10.1186/1471-230X-10-95

Zapata PJ, Navarro D, Guillén F, Castillo S, Martínez-Romero D, Valero D, Serrano M (2013). Characterisation of gels from different Aloespp. as antifungal treatment: Potential crops for industrial applications. Industrial Crops and Products 42:223-230. https://doi.org/10.1016/j.indcrop.2012.06.002

Zhao HC, Qin R, Chen XX, Sheng X, Wu JF, Wang DB, Chen GH (2006). Microvessel density is a prognostic marker of human gastric cancer. World Journal of Gastroenterology 12(47):7598. https://www.wjgnet.com/10079327/full/v12/i47/7598.htm
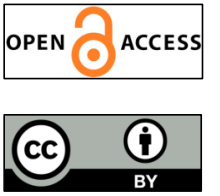

The journal offers free, immediate, and unrestricted access to peer-reviewed research and scholarly work. Users are allowed to read, download, copy, distribute, print, search, or link to the full texts of the articles, or use them for any other lawful purpose, without asking prior permission from the publisher or the author.

License - Articles published in Notulae Botanicae Horti Agrobotanici Cluj-Napoca are Open-Access, distributed under the terms and conditions of the Creative Commons Attribution (CC BY 4.0) License. (c) Articles by the authors; UASVM, Cluj-Napoca, Romania. The journal allows the author(s) to hold the copyright/to retain publishing rights without restriction. 